Andrzej Dąbrówka

Warszawa

\title{
Mediewistyka: Średniowiecze, historia, badania - portal internetowy
}

Minęło osiem lat, odkąd istnieje portal mediewistyczny pomyślany jako „miejsce wymiany wiadomości i publikacji między przedstawicielami różnych dyscyplin i środowisk mediewistycznych w Polsce”. Obecnie mieści się w domenie mediewistyka.pl/, przedtem mediewistyka.net/.

Obecny portal miał już swoją historię, zanim w maju 2005 połączyłem w nowym oprogramowaniu Mambo trzy starsze strony związane z mediewistyką. Pierwsze były z 1997 r. - moja osobista strona, dziś istniejąca jako zabytek mediewistyka.pl/dab oraz Mediewistyka literacka $w$ Polsce, podwieszona jeszcze jako zabytek do mediewistyka.pl/lit (Proszę ich nie oglądać!). Najważniejszą funkcją tej ostatniej była obsługa cyklicznej konferencji „Spotkania Mediewistyczne”. Drugi zespół to strony powstałe na potrzeby Stałego Komitetu Mediewistów Polskich, który obecnie przekształca się $\mathrm{w}$ towarzystwo naukowe. $\mathrm{Z}$ inicjatywy SKMP powstał w 2004 r. opis środowisk mediewistycznych (Regiony) i zapoczątkowano gromadzenie sylwetek indywidualnych polskich badaczy średniowiecza (Sylwetki). W obecnej postaci włączono tu biogramy wcześniej zgłaszane do strony „Adresy i specjalności”, będącej częścią „Mediewistyki literackiej w Polsce". Za trzeci składnik obecnego portalu można uznać forum „Mediewistyka polska. Informacje i debaty służące promocji badań naukowych nad średniowieczem w Polsce”. Stworzyłem je 29 maja 2003. Jego żywot zakończył się paskudnym zhakowaniem w kwietniu 2005, kiedy to jakiś człowiek „mądry inaczej” chciał mi udowodnić, że posługiwałem się kiepskim, podatnym na zniszczenie oprogramowaniem. Sam jednak nie umiał spakować całej bazy danych, którą mi niby honorowo przysłał. W efekcie, z powodu jego błędów, nie dało się jej odtworzyć i Forum musiało być zakładane na nowo, a po starym został tylko plik tekstowy.

Szczegóły tamtych perypetii opowiada notka założycielska, przyklejona na dole podstrony Aktualności. 
Często odwiedzaną częścią Portalu jest Czytelnia. Umieszczałem tam artykuły a nawet całe książki, częściej zaś ich próbki. Poniżej przegląd działów i przykładowe pozycje o najlepszej oglądalności:

Bibliografie (8 pozycji)

E. Jung - Bibliografia ttumaczeń tekstów filozoficznych

wejścia

H. Anzulewicz - Albert Wielki - badania i edycje jego dziet

Recenzje - nowe i przedruki (5 pozycji)

W. Mischke - Adhortacja biskupa Wojciecha Stawnikowica

11981

Źródła - nowe edycje i przedruki (7 pozycji)

P. Radziłowski - An unknown source for Jan Dtugosz...

8524

Dialogus magistri Polycarpi cum morte

Książki (13 pozycji )

Z. Kadłubek (UŚ) - Rajska radość. Św. Piotr Damiani

A. Wolański, Dramat liturgiczny w średniowieczu

Artykuły i referaty (28 pozycji)

R. Knapiński (KUL) - Biblia Pauperum - Rzecz o dialogu stowa $i$ obrazu

M. Sakowska - Eacinskie teksty autorstwa kobiet w epoce

ponad 43 tys. średniowiecza

P. Morawski - Gardzienickie Carmina Burana

Prace studenckie (dyplomowe i referaty)

K. Glińska, Geta i Totenfresser

Nowe publikacje można samemu prezentować na Forum w dziale Serwis bibliograficzny.

\section{Podsumowanie}

Pierwsze statystyki z 24 października 2004 wykazują 73 odwiedziny. Od tamtej pory portal miał 1.175 tys. wizyt, 430 GB transferu. W najlepszych latach zaglądało tu średnio 300 różnych osób dziennie, a liczba tzw. unikalnych gości wyniosła łącznie prawie 800 tys. Liczba wejść spadała od paru lat, a po zmianie domeny w połowie 2012 roku spadła do około 100 unikalnych gości dziennie.

Od paru lat mało się dzieje na Forum, którego 347 zarejestrowanych użytkowników napisało w sumie 553 posty na 424 tematy. Odwiedzono 
je już 194878 razy. Nigdy tam nie toczyły się dłuższe dyskusje niż trzyczteroosobowe.

Nieco lepiej jest na głównym portalu, ale tylko dlatego, że tam jako tako działa kalendarz konferencji, do którego co jakiś czas ktoś przysyła mi zawiadomienie.

Przyczyną jest mniejsze zainteresowanie ze strony Kolegów, którzy powszechniej sami sobie tworzą strony lub otrzymują uczelniane prezentacje i nie potrzebują takiej platformy. Wizytówki regionów nie są aktualizowane, nie przybywa sylwetek. Kalendarz wydarzeń jest dziurawy, struktura innych działów jest zalążkowa.

Ja z kolei też nie mogę poświęcać się aktywnie pozyskiwaniu materiałów do czytelni, czy nawet do Kalendarza konferencji. Materiały do Czytelni trzeba redagować, przeszukiwanie planów konferencyjnych na uczelniach zabiera czas.

Portal jest zaniedbany gdyż niedoinwestowany. Nie dość, że sam płacę za wszystko, to nie mam z tego właściwie żadnej satysfakcji. Zdarzyło się, że odmówiono mi udziału w kongresie PTH w 2009 roku, a jednocześnie zaproponowano tam, aby zwrócić się do mnie o stworzenie internetowego czasopisma historycznego.

Konserwacja, obsługa bieżąca, pilnowanie go przed inwazjami nieproszonych gości - to wszystko nie jest przyjemne.

Nie stać mnie niestety, aby zatrudniać administratora merytorycznego.

Podsumowując zatem dość minorowo: cały portal pozostał na poziomie amatorskiego eksperymentu, który bez dofinansowania nie ma w gruncie rzeczy racji bytu. 
